\title{
What Do the Angels Say? Alterity and the Ascents of Emanuel Swedenborg and the Baal Shem Tov
}

\section{https://doi.org/10.1515/opth-2018-0032}

Received June 10, 2018; accepted August 28, 2018

\begin{abstract}
This paper examines the history of boundary crossing and boundary preservation between Jews and Christians in the eighteenth century via an unorthodox path. Two men, a Swedish Lutheran natural philosopher and a charismatic Polish Rabbi, give their accounts of ascents to the heavens, both in the 1740s. The lives of Emanuel Swedenborg and the Baal Shem Tov did not intersect, but their otherworldly experiences tell related stories of strife between Jews and Christians while betraying something of a shared horizon concerning the future of their religious communities, and concerning sacred texts and their interpretation. Using a phenomenological framework informed by Emmanuel Levinas, and with theories of experience articulated by Steven Katz and Martin Jay at hand, this paper understands these accounts as articulations of relationship: not just the relationship between the subject and God, scripture, or the heavens, but articulations of the fraught relationship with the religious other in the earthly, human realm. By placing Swedenborg and the Besht, as it were, face to face, this paper emphasizes the presence of the religious other in their experiences, even in their private encounters with the Divine, and even though the intersubjectivity these experiences expose is characterized by difference, difficulty, and asymmetry.
\end{abstract}

Keywords: Emmanuel Levinas; Jewish-Christian relations; religious experience; Emanuel Swedenborg; Baal Shem Tov; phenomenology; scripture; Hasidism; eighteenth century; Kabbalah; alterity

The eighteenth century was a time of contradictions and counter-movements in Jewish-Christian relations. It was an era when Jewish and Christian philosophers could investigate together the mysteries of the universe owing to the purported victory of reason and enlightenment, while blood libels, forced conversions and Talmud burnings persisted, like gruesome echoes from a past age. The successes and failures of Jewish-Christian relations in the eighteenth century can be viewed in light of perceptions of self and other that characterize the age. In the terms of Emmanuel Levinas, the totality of "the same" that characterized perceptions of the self in Western philosophical discourse, ${ }^{1}$ was shaped in the eighteenth century by new forms of encounter and confrontation with radical alterity, or "the other." Long-standing patterns in the ways Jews and Christians understood themselves over and against the other took new forms, particularly as European encounters with unfamiliar territories and native populations to the west, to the south, and to the east impacted Christian self-identity. As the work of Guy Stroumsa and Jonathan Boyarin has demonstrated, for instance, the discourse concerning the Jews, as "foreigners within," was analogous

1 Levinas, Totality and Infinity, 21, 43.

*Corresponding author: Rebecca Esterson, Graduate Theological Union, Berkeley, United States of America;
E-mail: resterson@gtu.edu 
to the discourse concerning the inhabitants of these exotic lands. ${ }^{2}$ Furthermore, intra-Christian hostilities between Protestants and Catholics in this century utilized Jews as a negative foil, in some cases with violent results, as Magda Teeter argues. ${ }^{3}$ We might ask, therefore, from a phenomenological perspective, how perceptions of the same and the other manifested in the religious imagination of Christians and Jews against this backdrop.

This paper will examine this history of boundary crossing and boundary preservation between early modern Jews and Christians via an unorthodox path. Two men, a Swedish Lutheran natural philosopher and a charismatic Polish Rabbi, give their accounts of ascents to the heavens, both beginning in the 1740s. The lives of Emanuel Swedenborg and the Baal Shem Tov (hereafter referred to as the Besht) did not intersect, but their other-worldly experiences tell related stories of strife between Jews and Christians while betraying something of a shared horizon concerning the future of their religious communities, and concerning sacred texts and their interpretation. For our sake here, their conversations with angels and departed souls are revealing, not only for their descriptions of transcendent realities, but because they betray the contours of the religious landscape of their contexts. We will consider each man's ascents to the upper worlds and return to their communities as instances that inform our understanding of Jewish-Christian relations and biblical interpretation in an age when reason and experience were often viewed as rival ways of knowing.

It is important to note at the outset the lack a disinterested vocabulary for discussing the quality of such accounts as these. What we have so far described as events of the "religious imagination" and the "ascents to the heavens," tend to be described similarly in one of two directions: they are internal processes, such as "fantasies" or "dreams," or external processes, such as "visions" or "mystical encounters." Acknowledging this lexical challenge, this paper will walk the line, so to speak, and deny neither the interiority not the exteriority of experience. In his influential work on the topic of mystical experience, Steven Katz writes that there are "NO pure (i.e. unmediated) experiences." And that "in order to understand mysticism it is not just a question of studying the reports of the mystic after the experiential event, but of acknowledging that the experience itself as well as the form in which it is reported is shaped by concepts which the mystic brings to, and which shape, his experience." ${ }^{4}$ In other words, experience should not be understood as acultural, or ahistorical.

In his study on the idea of experience in early modernity, Martin Jay echoes Katz's perspective, and considers the post-structuralist challenge to traditional views of experience, noting that we have come to understand experience as "always already mediated." Jay warns us, however, of a position that solely focuses either on private subjectivity or on the shared linguistic world of community and context. In his view, experience is best appreciated precisely at the tension point between these polls of subjectivity and objectivity. Thus, accounting for whatever "remainder" escapes the grasp of the signifier, experience results from the oscillation between the self and what is outside the self. It is "acquired through an encounter with otherness." ${ }^{\prime}$ This is helpful to our understanding of the reports of mystical experiences we will consider here, in that we understand them as articulations of relationship: not just the relationship between the subject and God, scripture, or the heavens, but articulations of the fraught relationship with the religious other on the earthly, human realm.

This leads us again to the work of Levinas, who suggests that one's access point to the transcendent, the infinite, and the invisible is in fact one's encounter with the "welcome of the other" in their naked face. ${ }^{7}$ The experiences of the transcendent that we will consider here were not immediately triggered by the event of standing face to face with the otherness of the other, as Levinas would have it. In each case, as far as we know, the experiencer was either alone or with close community members when the ascents occurred. Rather, experience, in these instances, is triggered by the anxiety of otherness, as we will see. This study

2 See Stroumsa, A New Science: The Discovery of Religion in the Age of Reason, 41; and Boyarin, The Unconverted Self: Jews, Indians, and the Identity of Christian Europe.

3 See Teter, Sinners on Trial, 126-156.

4 Katz, "Language, Epistemology, and Mysticism," 26.

5 Jay, Songs of Experience: Modern American and European Variations on a Universal Theme, 3.

6 Ibid., 6-7.

7 Levinas, Totality and Infinity, 197. 
will intentionally interface the experiences of Swedenborg and the Besht, not for the sake of illustrating their sameness-Levinas's view of true encounter is the encounter with difference-but for illustrating the intersubjectivity of eighteenth century Jews and Christians from a phenomenological perspective. This does not, therefore, deny the interior realities of the experiencing subject, but probes the symbolic potential of the visions for their relevance to our understanding of particular historical locations. We will briefly look at each case before further analyzing the significance of their comparison.

Emanuel Swedenborg was the son of a prominent Swedish Lutheran Bishop, a natural philosopher, inventor, assessor for the Swedish Board of Mines, frequent guest of King Charles XII and correspondent with members of the Royal Academies in London and Paris. Difficulties with a speech impediment kept him from certain types of public engagement, such as university lecturing, but he made up for this by publishing prolifically. His scientific writings cover such wide-ranging topics as Stereometry, New Arithmetic, Finding Longitudes, Hydrostatics, Swedish Currency and Finance, The Cerebrum, and many more. Beginning in the 1740 's, after working to build his career in the secular world, Swedenborg began experiencing tumultuous dreams and later waking visions of Christ, angels, and spirits from other worlds, all of which he recorded in his journals with the tone of a curious scientist. The remaining three decades of his life would be dedicated to the authorship of more than 30 theological volumes, including an eight volume spiritual sense commentary on Genesis and Exodus, his opus Arcana coelestia. All of this interpretive and theological work was informed by "things seen and heard" while visiting spiritual worlds.

The format of Arcana ceolestia, which interposes Bible commentary with detailed descriptions of life after death, of heavens and hells and worlds in between, is indicative of Swedenborg's overarching message. He believed he was witnessing the inauguration of a new age of freedom and access to spiritual wisdom; that his ascents to other worlds coincided with the opening up of the inner sense of scripture and that his experiences were a symptom of a much larger event, or a spiritualized apocalypse. This new age was signified, in one particular vision, by a Temple in heaven, with the following inscription written over the door: "Nunc liceat intellectualiter intrare in arcana fidei." (It is now permitted to enter with understanding into the mysteries of faith). ${ }^{8}$ In his view, the true nature of scripture was opening and revealing itself to the world, through Swedenborg, a self-described servant of the returning Christ, and that through scripture heaven and earth were united. "From much experience it has been given me to know that the Word opens Heaven to man, that is, that when man reads the Word or speaks from it, communication is effected with heaven." ${ }^{9}$ He describes this in one vision as follows:

Once there was sent me from heaven a little paper written over with Hebrew letters ... The angel who was with me said that he knew whole meanings from the letters themselves; that every letter had its own meaning, and that they knew that meaning from the curves of the lines in each letter, besides they knew the subject from each letter by itself. .. And thus the Word is so written in many places, whereby when it is read by a Jew or a Christian in the Hebrew text, it may be known in the third heaven what the very letters signify. ${ }^{10}$

Swedenborg's visions may have been sensational, especially for a natural philosopher, and indeed they created quite a commotion among his early readers, including the likes of John Wesley and Immanuel Kant, his heaven nevertheless presented as strikingly similar to his earth. ${ }^{11}$ According to Swedenborg, the spiritual worlds are many, and they are pluralistic, populated entirely by humans who once lived on earth and maintain their key identifying features such as gender, ethnicity, and religious and national affiliation. There are communities of Catholics, of Protestants, of Muslims, and of Jews. There are Africans, Germans, Dutch, English and Moravians. Stereotypes, both negative and positive, abound in Swedenborg's descriptions of what these spirits are like. Nevertheless, he perceived a heaven that requires human diversity, a heaven that was not reserved for Christians alone. In Swedenborg's heaven: "variations that stem from the difference of activity from one community to another do not cause harm but bring benefit,

8 Swedenborg, True Christianity, 508.

9 Swedenborg, De verbo, 45.

10 Ibid., 14.

11 See for instance Wesley, “Thoughts on the Writings of Baron Swedenborg,” and Kant, Dreams of a Spirit Seer. 
because they are the source of heaven's perfection."12

However, it is the Jews of the other world that preoccupy Swedenborg more than any other group in his Arcana coelestia, and his descriptions are worth pausing over for what they can tell us about JewishChristian relations and biblical interpretation in his time. The Jews described in Arcana coelestia do not understand the true spiritual sense of their own scriptures. He writes: "they did not know and do not know of the existence of the internal man, or of anything internal, for if they had known of it, or if they now knew of it, so as to acknowledge it, such is their character that they would profane it ..." ${ }^{13}$ On the one hand, Swedenborg's conception of the Jews as literalists, that they are limited to the "external sense," draws on stereotypes with deep roots in Christian exegesis, going back to Jerome, Augustine, Luther, and many more. Against the background of a rising preference for literalism in post-reformation circles, however, Swedenborg's use of the old trope stands out, with the effect of defending his allegorical approach as essentially Christian even as it bucks the trend of the day. ${ }^{14}$ Furthermore, as many of his readers noted, the parallels to Kabbalah in his commentaries are hard to ignore, especially given the contexts of his intellectual and relational orbits, contexts that were heavily indebted to kabbalistic thought. ${ }^{15}$ The absence of reference to Kabbalah in his vast and all-encompassing corpus of writing is especially curious given his context and given his shared horizon with kabbalistic exegetical themes, and suggests a conscious or unconscious erasure is at play. ${ }^{16}$

A further complication relates to Swedenborg's descriptions of conversations with Jews in the spiritual world. While his this-worldly contact with Jewish interlocutors was heavily mediated through Christian sources he records many accounts of celestial dialogues with Jews, in which they come across as stubborn, and unwilling to hear the true sense of scripture. ${ }^{17}$ These encounters bring to sharp focus the "phantom Jews" that populated the European imagination from ancient times. As David Nirenberg articulates in his history of anti-Judaism in the West, the figurative Jew has been conjured time and again as a constitutive idea in Christian thought, regardless of the presence or absence of actual Jews. ${ }^{18}$ As was the case in the past, Swedenborg's phantom Jews serve to distinguish Christian interpretive abilities and Christian self-identity, even when, or perhaps especially when, the interpretations themselves have something in common with Jewish ones.

It is an odd comparison, for a number of reasons, one that interfaces Swedenborg and the founder of Hasidism, Rabbi Israel Baal Shem Tov. It is one that I have not encountered in the existing literature. They are two mystics of the same age, and not all that far apart geographically, but our histories of Europe East and West, as well as our histories of early modern Judaism and Christianity, have too often been isolated. I hope to demonstrate, however, that theirs is a fruitful pairing, not just because of the nature of their experiences, but because of the anxieties of otherness that manifest, even amidst the opening of heaven's gates. In setting Swedenborg's visionary and exegetical perspective alongside that of the Besht, we do well to bear in mind Levinas's concept of asymmetry. Swedenborg's visions engage in a totalizing discourse of the Jew that he inherited from both enlightenment natural philosophy and Swedish Lutheranism. The Besht's visions engage the experience of his community as the persecuted other, as we will see. The right of the Other over egoism, as described by Levinas, is relevant to our comparison, as it aids in our interpretation of intentionality in each case by highlighting the disparity between them. ${ }^{19}$

12 Swedenborg, Heaven and Its Wonders and Hell, 56.

13 Swedenborg, Arcana caelestia, 302.

14 On the post-Reformation preference for the literal sense and its connection to the scientific revolution, see Harrison, The Bible, Protestantism, and the Rise of Natural Science.

15 Especially influential in this regard were Swedenborg's brother-in-law Eric Benzelius and the German philosopher Gottfried Wilhelm Leibniz, both of whom studied Kabbalah.

16 For a full presentation of this argument, see Esterson, "Secrets of Heaven: Allegory, Jews, the European Enlightenment and the Case of Emanuel Swedenborg," chapter 3.

17 See, for instance, Swedenborg, True Christianity, 226.

18 See Nirenberg, Anti-Judaism: The Western Tradition, 1-12. On the idea of the phantom Jew, see also Klepper, The Insight of Unbelievers: Nicholas of Lyra and Christian Reading of Jewish Text in the Later Middle Ages, chapter 5; and Goshen-Gottstein, "Foundations of Biblical Philology in the 17th Century: Christian and Jewish Dimensions," 81.

19 Levinas, Totality and Infinity, 40. 
Due to the limited parameters of this study, we will not be able to present a full analysis of the historical forces common to both men, such as the Great Northern War between Sweden and Russia, the ongoing and often violent reverberations from the Protestant Reformation, the European Enlightenment and Haskalah, Deism, pietism, the influence of Kabbalah through both Christian and Jewish channels, the fall of Sabbatai Zevi, and many other social, religious and political events. We are also not able here to flesh out the many significant similarities and differences between the teachings of these two men, though I hope to highlight a few by the time we are through. It will be important, however, to underscore the following critical difference. While Swedenborg recorded his own experiences and commentaries by hand in countless manuscripts, published and unpublished, we have very little written by the Besht himself. Most of what we know of him comes from accounts that circulated orally between those in his inner circle and their disciples, accounts that were published decades after his death, such as we have in the compilation, Shivhei ha-Besht. ${ }^{20}$ Even those sources we have from the Besht himself, such as the famous letter to his brother-in-law in Israel, Gershon of Kutow, exist in different manuscript versions, and we are left sorting through various scholarly reconstructions and hypotheses of authenticity. ${ }^{21}$ For the sake of this paper I will be following the work of Immanuel Etkes, and will draw on accounts of the Besht's ascents to upper worlds from the letter manuscripts and from Shivhei ha-Besht that he deems trustworthy.

We do know that the Besht was one of many Ba'alai Shem, literally "masters of the name," in southern Poland in the eighteenth century. The Ba'alai Shem were sought after as experts in practical kabbalah, healers, performers of exorcisms, and as intermediaries between upper and lower worlds. The Besht did all of these things, and rose to prominence as a leader and advocate of a people and a Torah under threat of persecution, both physical and spiritual persecution in each case. His prayers for intersession were said to reach the heavens, and as we will see, save his people from disease and libel, and save the Torah from censorship and even destruction. He was a traveler, both horizontally and vertically, as it were, gathering charms and wisdom for the sake of the health of his community. He received kavanot, intentions or inner meanings of Torah, from the ancient prophet Ahijah the Shilonite, whom he referred to has his rabbi. And he assisted in the spiritual ascents of other souls, encouraging and enabling yihuddim, or mystical unifications. I would like to very briefly summarize two examples of his spiritual ascents.

The first is from the letter written to his brother-in-law, or the "Holy Epistle" as it is sometimes called. The letter tells the story of the ascent of the Besht's soul on Rosh Hashana, 1747 (5507 in the Hebrew calendar). Upon entering a place he calls the "Lower Garden of Eden" he sees the souls of the living and the dead, ascending and descending "from world to world via the pillar familiar to those who know mysteries." He witnesses wicked souls repenting and being lifted up, and all the souls express great happiness at seeing the Besht there and address him personally: "Your honorable Torah eminence, the Lord has granted you the extra intelligence to discover and comprehend these matters; you shall ascend together with us and be our helper and provider and support." He ascends with them, and comes upon the angel Michael, before whom the ministers of the nations humble themselves as he showers gifts down on them "like at the giving of the Torah.” The Besht is frightened at this scene, and ascends higher to a palace where he finds the Messiah King himself engaged in Torah study. He stands face to face with the Messiah and is shown "wonderful and awesome things in the profundities of Torah that I had not seen or heard and that no ear had heard for some years. .." He asks the Messiah if the time has come for his arrival, and the Messiah responds that the time would come only when the Besht's own wisdom becomes widely known and others are able to perform yihuddim and accents like him. ${ }^{22}$ Curiously, the Besht is then taught three charms and three holy names,

20 For English translation, see In Praise of the Baal Shem Tov [Shivhei ha-Besht]: The Earliest Collections of Legends about the Founder of Hasidism.

21 Moshe Rosman, for instance, prefers the Bauminger manuscript version and against the authenticity of Shivhei ha-Besht. Immanuel Etkes prefers Mondshine manuscript version, and argues that discrepancies are likely due to the Besht himself writing two different accounts of the same experience. Etkes also trusts Shivhei ha-Besht. See Rosman, Founder of Hasidism: A Quest for the Historical Ba'al Shem Tov, 97-105; and Etkes, The Besht: Magician, Mystic, and Leader, 3-6. For a critical analysis of the various scholarly reconstructions of the Besht's accounts, including Etkes's, see the recent dissertation by Chaim E. Moseson, "From Spoken Word to the Discourse of the Academy: Reading the Sources for the Teachings of the Besht." 22 Etkes, The Besht, 274-276. 
but is forbidden from sharing them, producing an ambiguity about the messianic age that the Besht himself finds puzzling. However, he is permitted to share the following with his brother-in-law:

While you are praying or studying, in each and every utterance and issuance from your lips understand how to make a unification of it, for in each and every letter there are worlds and souls and divinity which rise and commune and bind each other to Godliness and afterward the letters commune and unify thoroughly and form a word and are completely unified with godliness and you will include your soul with them at each and every level of the above and all the worlds will unify as one and rise and make unaccountable joy and delight; if you can conceive of the joy of bride and groom in smallness and materiality, so much more it is in this upper level. ${ }^{23}$

The letter concludes with a final account of his journey, in which the Besht returns to the scene of the ministers bowing to the archangel, and finds Samael among them, the mythical accuser and prosecutor of the Jewish people. In anger he confronts Samael about the suffering of his people on earth, their forced conversions and martyrdom. Samael defends these events, saying that they were permitted in order to dissuade future generations from conversion. In an account of a second ascent three years later the Besht confronts Samael as he is presiding over a great and evil council, who are about to sentence the Jewish people to utter destruction by way of the plague. The Besht intervenes and bargains with special prayers to stay the sentence and prevent the plague from reaching his community. ${ }^{24}$

Another account of an ascent of the Besht comes from a third person report recorded in Shivhei ha-Besht. The ascent takes place on Yom Kippur in the synagogue. The Besht had been deeply grieved at perceiving ("seeing") an evil decree, that the Oral Torah would be taken away from Israel. He perceived that the decree was growing stronger during the Kol Nidrei service, and as he was leading the closing prayers and reciting the words "Open for us a gate," he was overcome and fell into a trance. He later recounted his ascent, whereby he found himself passing from world to world, traveling freely until he came upon fifty years of prayers that had become stuck, unable to ascend themselves until the Besht and his community prayed during this service with "proper kavannah." He began to move with the prayers upward, until an angel arrived and shut and bolted the gate, baring their entrance. Neither he nor his Rabbi, Ahijah, were able to move the bolt. His Rabbi then lead them to the palace of the Messiah where they were given two glyphs, or holy letters of the alphabet, with which they were able, finally, to open the gate and release the prayers. "And as a result of the rejoicing for the ascension of all the prayers the Accuser fell silent and I did not have to plead the case, the decree was canceled, and all that remained of it was the trace of the decree." 25

Etkes, and others, connect the evil decree annulled by the ascent of the Best to events surrounding the burning of the Talmud in Podolia in 1757. This was part of an upsurge of blood and host desecration libels against the Jews of the Polish-Lithuanian Commonwealth in the eighteenth century. These events haunted the Jews of Poland, and resulted in widespread insecurities regarding the fate of their texts as well as their very lives. ${ }^{26}$ Magda Teeter argues that the blood libel cases in Poland-Lithuania resulted from intra-Christian hostilities regarding the transubstantiation debate: that the Jews were a convenient foil in Catholic attempts to prove the holiness and flesh-like quality of the host. The relatively recent transfer of judicial powers from sacred to secular courts renewed threats of libel against Jews, who now faced formal charges of criminal activity at the hands of their zealous accusers. ${ }^{27}$ All of this provides a backdrop for interpreting the evil councils and heavenly courts that appear again and again in the tales of the Besht. Certainly, we can point to the examples of heavenly judges and courts in biblical and rabbinic literature long before the Besht ascended. But the self-understanding of the Besht as intercessor and defender on high of the Jewish people collectively, uniquely reflects the anxieties of his own community.

Scholars of Jewish mysticism have come to be weary of narratives of collective trauma as a means to explain mystical movements in Judaism, and it is not my intention to suggest any particular crisis caused

23 Quoted in Etkes, The Besht, 276-277.

24 Etkes, The Besht, 90.

25 Ibid., 92-93.

26 Ibid., 94-95.

27 Teter, Sinners on Trial: Jews and Sacrilege after the Reformation, 63-88. 
the Besht's visions or the emergence of Hasidism. ${ }^{28}$ Neither is it my suggestion that inherited anxieties about Jews and Christian identity caused Swedenborg's visions or conversations with Jews in the spiritual word. Influence, or causation, is overdetermined in both cases. My argument is that, in Katz's terms, the pre-experiential patterns of these two men, in particular, their anxieties about self-identity and other, materialize, as it were, in heaven, allowing a kind of engagement.

In setting the experiences of these two mystics against the phenomenological framework of Levinas, I am aware of the obvious contradictions. Levinas, while drawn to interpretations informed by Kabbalah, explicitly rejected "Hasidic excesses."29 More generally, he preferred a transcendence triggered by and grounded in the face-to-face encounter with another person, over and against disconnected upward movements of the spirit. The reification of religious sentiments in the images of angels and heavenly landscapes is perhaps more "totality" than "infinity" in Levinasian terms. Indeed, it is precisely the enlightenment critique of religious certitude that inspired a 2001 volume reading Levinas in the spirit of long eighteenth century. Its editor, Melvyn New, writes that the long eighteenth century, "from Spinoza to Kant, established the basis for present-day suspiciousness concerning the origins of the ethical-and most particularly, of anything suggestive of transcendent origin." ${ }^{30}$

And yet, I suggest Levinas is a fruitful partner in exploring this territory. One could point to Levinas's interest in scripture and its interpretation or his interest in the repair of relations between Jews and Christians as points of convergence with the content of this paper. ${ }^{31}$ However, it is his articulation of a metaphysics grounded in encounter with the other that informs the comparison at hand. While Katz highlights the interiority of mystical experience, the ways experience aligns with the ego, or perhaps "the same," Levinas insists that the other can draw one out of oneself to an encounter with what is infinitely and absolutely exterior. In the cases of Swedenborg and the Besht, it is not a positive encounter with the religious other that triggered their ascending souls. But the other comes along nevertheless. Success in reaching the Divine with holy texts counters a failure to reconcile on earth. Both men witnessed the opening of gates once closed, signaling a new access to divine truth, which is imparted, in turn, to those in their respective communities. And yet their own religious communities remain, for the most part, segregated. By, in a sense, placing them face to face, we have emphasized the intersubjectivity of Jews and Christians even in their private encounters with the Divine and even when the intersubjectivity is characterized by difference, difficulty, and asymetry.

For both Swedenborg and the Besht, the world they encountered above reflected the world below in important ways, and ways we might not expect. Their heavens, or spiritual worlds, or upper levels, contained spaces of conflict, legal spaces, spaces for religious disagreement and debate, uncomfortable spaces and uncomfortable encounters. And in both cases, they are given access to a means of reading and interpreting scripture that brings about unification with heaven and with God. A fuller analysis of these accounts would reveal articulations of the role of private and communal religious activity, the bestowal of authority to interpret, and the refocusing or shifting of messianic expectations. Indeed, if we had time, we could draw out a rich correspondence between the biblical commentaries of early Hasidism and Swedenborg's spiritualized, internalized, psychologized, approach to scripture. And yet their differences are at least as significant as their similarities. That Swedenborg's visions and commentaries ring with a note of enlightenment progress, science, and a new age, while the Besht's carry a tone of survival and the witness and repair of the suffering of the Jewish people, speaks to their respective circumstances. As in heaven, so upon the earth. Or to quote the Zohar "the lower creation corresponds to the higher." 32 Together, the ascents of the Besht and Swedenborg speak to the fraught history of two ancient and interconnected traditions whose depths of pain and heights of ecstasy seem only to be pronounceable in the words of angels.

28 For an example of the argument that Hasidism arises out of crisis, see Dinur, "The Origins of Hasidism and Its Social and Messianic Foundations.” Moshe Rosman counters this argument by drawing out the relative stability and prosperity of the Besht's context. See Rosman, Founder of Hasidism, 42-63.

29 Wolfson, "Secrecy, Modesty, and the Feminine: Kabbalistic Traces in the Thought of Levinas," 53.

30 New, "Preface: Something New Under the Sun," xv.

31 Levinas participated in a 1973 Commission of Experts, for instance, who drafted the statement titled "Christianity in Jewish Theology" in response to Nostra aetate.

32 Zohar I, 240b, quoted in Fine, “Kabbalistic Texts,” 325. 


\section{References}

Boyarin, Jonathan. The Unconverted Self: Jews, Indians, and the Identity of Christian Europe. Chicago: University of Chicago Press, 2009.

Dinur, Benzion. "The Origins of Hasidism and Its Social and Messianic Foundations." In Essential Papers on Hasidism, edited by Gershon David Hundert, 86-209. New York: New York University Press, 1991.

Etkes, Immanuel. The Besht: Magician, Mystic, and Leader. Translated by Saadya Sternberg. Waltham, MA: Brandeis University Press, 2005.

Goshen-Gottstein, Moshe. "Foundations of Biblical Philology in the 17th Century: Christian and Jewish Dimensions." In Jewish Thought in the Seventeenth Century, edited by Isadore Twersky and Bernard Septimus, 77-94. Cambridge, MA: Harvard University Press, 1987.

Esterson, Rebecca. "Secrets of Heaven: Allegory, Jews, the European Enlightenment and the Case of Emanuel Swedenborg." PhD. diss., Boston University, 2017.

Fine, Lawrence. "Kabbalistic Texts." In Back to the Sources: Reading the Classic Jewish Texts, edited by Barry W. Holtz, 305-359. New York: Simon \& Schuster, 1984.

Hart, Kevin and Michael A. Singer. The Exorbitant: Emmanuel Levinas Between Jews and Christians. New York: Fordham University Press, 2010.

Harrison, Peter. The Bible, Protestantism, and the Rise of Natural Science. Cambridge: Cambridge University Press, 1998.

In Praise of the Baal Shem Tov [Shivhei ha-Besht]: The Earliest Collections of Legends about the Founder of Hasidism, translated and edited by Dan Ben-Amos and Jerome R. Minz. Bloomington: Indiana University Press, 1970.

Jay, Martin. Songs of Experience: Modern American and European Variations on a Universal Theme. Berkeley: University of California Press, 2005.

Immanuel Kant. Dreams of a Spirit Seer. Translated by John Manolesco. New York: Vantage Press, 1969. Published originally as Träume eines Geistersehers, erläutert durch Träume der Metaphysik, 1766.

Katz, Steven. “Language, Epistemology, and Mysticism.” In Mysticism and Philosophical Analysis, edited by Steven Katz, 22-74. New York: Oxford University Press, 1978.

Klepper, Deeana. The Insight of Unbelievers: Nicholas of Lyra and Christian Reading of Jewish Text in the Later Middle Ages. Philadelphia: University of Pennsylvania Press, 2007.

Levinas, Emmanuel. Totality and Infinity. Translated by A. Lingis. Pittsburgh, Pa: Duquesne University Press, 1969.

Moseson, Chaim E. "From spoken word to the discourse of the academy: reading the sources for the teachings of the Besht." PhD. diss., Boston University, 2017.

New, Melvyn. In Proximity: Emmanuel Levinas and the 18th Century. Lubbock, Texas: Texas Tech University Press, 2001.

Nirenberg, David. Anti-Judaism: The Western Tradition. New York: W. W. Norton \& Company, 2013.

Rosman, Moshe. Founder of Hasidism: A Quest for the Historical Ba'al Shem Tov. Berkeley: University of California Press, 1996.

Stroumsa, Guy. A New Science: The Discovery of Religion in the Age of Reason. Cambridge, MA: Harvard University Press, 2010.

Swedenborg, Emanuel. Arcana caelestia: Principally a Revelation of the Inner or Spiritual Meaning of Genesis and Exodus, translated by John Elliott. London: The Swedenborg Society, 1983-1999. Published originally in 1749-54.

Swedenborg, Emanuel. De verbo. Translated by John Whitehead. London: Swedenborg Society, 1934. Originally published posthumously in 1854.

Swedenborg, Emanuel. Heaven and Its Wonders and Hell. Translated by John C. Ager. West Chester, Pennsylvania: Swedenborg Foundation, 2009. Published originally as De Coelo et Ejus Mirabilibus, et de Inferno, ex Auditis et Visis, 1758.

Swedenborg, Emanuel. True Christianity. Translated by Jonathan Rose. West Chester, PA: Swedenborg Foundation 2006. Published originally as Vera Christiana religio, 1771.

Teter, Magda. Sinners on Trial: Jews and Sacrilege after the Reformation. Cambridge, MA: Harvard University Press, 2011.

Wesley, John. "Thoughts on the Writings of Baron Swedenborg." In The Works of the Rev. John Wesley, A. M., edited by John Emory, XII, 426-441. New York: B. Waugh and T. Mason, 1835.

Wolfson, Elliot. "Secrecy, Modesty, and the Feminine: Kabbalistic Traces in the Thought of Levinas." In The Exorbitant: Emmanuel Levinas Between Jews and Christians, edited by Kevin Hart and Michael A. Singer, 193-224. New York: Fordham University Press, 2010. 